\title{
CONTENTS INDEX
}

VOLUME 6, 1996

\section{CONTENTS}

\section{Original Contributions}

\section{J.H. Fuller}

O.I. Kolev

I.A. Altaparmakov

B. de Graaf

A.J. de Roo

H. Cohen

M. Karlberg

R. Johansson

M. Magnusson

P. Fransson

1 Comparison of Horizontal Head Movements Evoked by Auditory and Visual Targets

15 Changes in the Gastrointestinal Electric Pattern to Motion Sickness in Susceptibles and Insusceptibles During Fasting

23 Effects of Long Duration Centrifugation on Head Movements and a Psychomotor Task

31 Vertigo After Sailing a Nineteenth Century Ship

37 Dizziness of Suspected Cervical Origin Distinguished by Posturographic Assessment of Human Postural Dynamics

\section{Technical Note}

49 Fentazin Anesthesia for Labyrinthine Surgery in Guinea Pigs

\section{Short Communication}

53 Influence of Arousal and Attention on the Control of Postural Sway

I Vestibular Bibliography 


\section{CONTENTS}

\section{Original Contributions}

M.P. Torte-Hoba

J.H. Courjon

M.H. Leroy

N. Boyer

P. Dominey

F. Farhat

A. Reber

\section{S.M. Jones}

T.A. Jones

D. Nuti

S. Passero

S. Di Girolamo

J.M. Furman

J.C. Mendoza

K.A. Cortopassi

E.R. Lewis

M. Suzuki
A. Kadir
N. Hayashi
M. Takamoto

N. Takeda

K. Hashikawa

H. Moriwaki

N. Oku

I. Koizuka

T. Kitahara

N. Taya

T. Kubo

T. Nishimura
61

Acetylcholinesterase Activity Changes in Medial Vestibular Complex After Hemilabyrinthectomy in the Rat

Short Latency Vestibular Evoked Potentials in the Chicken Embryo

Bilateral Vestibular Loss in Vertebrobasilar

Dolichoectasia

93 Visual-Vestibular Interaction During Off-Vertical Axis Rotation

High-Frequency Tuning Properties of Bullfrog Lagenar Vestibular Afferent Fibers

Functional Model of Benign Paroxysmal Positional Vertigo Using an Isolated Frog Semicircular Canal

Effects of Caloric Vestibular Stimulation on Parietal and Temporal Blood Flow in Human Brain: A Consecutive Technetium-99m-HMPAO SPECT Study 
Contents continued

J. Martin

D.P.D. Gilchrist

P.F. Smith

C.L. Darlington

M. Hawken

\section{Short Communication}

135 Early Diazepam Treatment Following Unilateral Labyrinthectomy Does Not Impair Vestibular Compensation of Spontaneous Nystagmus in Guinea Pig

\section{Book Review}

141 Vestibular and Neural Front, edited by K. Taguchi, M. Igarashi, and S. Mori

I Vestibular Bibliography 


\section{CONTENTS}

\section{Original Contributions}

R.D. Tomlinson

K.M.V. McConville

E.-Q. Na

C. Wall III

G.K. Arakawa

D. Nuti

P. Vannucchi

P. Pagnini

C.L. Darlington

P.F. Smith

D. Bridgeman

L. Hoffman

P.A. Wackym

P.E. Micevych

P. Popper

K. Citek

S.M. Ebenholtz
145 Behavior of Cells Without Eye Movement Sensitivity in the Vestibular Nuclei During Combined Rotational and Translational Stimuli

159 A Model That Relates Canal-Ocular to Otolith-Ocular Responses

173 Benign Paroxysmal Positional Vertigo of the Horizontal Canal: A Form of Canalolithiasis With Variable Clincial Features

185 The Recovery of Static Vestibular Function Following Peripheral Vestibular Lesions in Mammals: The Intrinsic Mechanism Hypothesis

203 Distribution of Choline Acetyltransferase mRNA in the Efferent Vestibular Neurons of the Chinchilla

213 Vertical and Horizontal Eye Displacement During Static Pitch and Roll Postures

I Vestibular Bibliography 


\section{CONTENTS}

\section{Original Contributions}

C.R. Gordon

O. Spitzer

I. Dowek

A. Shupak

N. Gadoth

K. Brantberg

P.-A. Fransson

J. Bergenius

A. Tribukait

H. Cransac

L. Peyrin

F. Farhat

J.M. Cottet-Emard

J.M. Pequignot

A. Reber

K.G. Rottach

R.D. von Maydell

A.O. DiScenna

A.Z. Zivotofsky

L. Averbuch-Heller

R.J. Leigh

N. Ohashi

G. Barnes

K.D. Powell

B.W. Peterson

J.F. Baker

J.L. Demer

E.S. Viirre

M. Aoki

H. Miyata

K. Mizuta

Y. Ito
Suppression, OKAN, and Head-Shaking Nystagmus at Long-Term Follow-Up After Unilateral Vestibular Neurectomy

243 Effect of Hemilabyrinthectomy on Monoamine Metabolism in the Medial Vestibular Nucleus, Locus Coeruleus, and Other Brainstem Nuclei of Albino and Pigmented Rats

255 Quantitative Measurements of Eye Movements in a Patient With Tullio Phenomenon

A Comparison of Predictive and Nonpredictive Ocular Pursuit Under Active and Passive Stimulation Conditions in Humans

277 Phase-Shifted Direction Adaptation of the VestibuloOcular Reflex in Cat

295 Visual-Vestibular Interaction During Standing, Walking, and Running

\section{Short Communication}

315 Evidence for the Involvement of NMDA Receptors in Vestibular Compensation

I Vestibular Bibliography 


\section{CONTENTS}

\section{Original Contributions}

I. Koizuka

R.H. Schor

J.M. Furman

R.S. Kennedy

L.J. Hettinger

D.L. Harm

J.M. Ordy

W.P. Dunlap

G.C. Mann

S.L. Whitney

M.S. Redfern

D.F. Borello-France

J.M. Furman

M.-L. Mittelstaedt

H. Mittelstaedt

L.J.G. Bouyer

D.G.D. Watt

L.J.G. Bouyer

D.G.D. Watt

L.J.G. Bouyer

D.G.D. Watt

Influence of Otolith Organs, Semicircular Canals, and Neck Afferents on Post-Rotatory Nystagmus

31 Psychophysical Scaling of Circular Vection (CV) Produced by Optokinetic (OKN) Motion: Individual Differences and Effects of Practice

Functional Reach and Single Leg Stance in Patients With Peripheral Vestibular Disorders

The Influence of Otoliths and Somatic Graviceptors on Angular Velocity Estimation

67 "Torso Rotation" Experiments; 1: Adaptation to Motion Sickness Does Not Correlate With Changes in VOR Gain

"Torso Rotation" Experiments; 2: Gaze Stability During Voluntary Head Movements Improves With Adaptation to Motion Sickness

"Torso Rotation" Experiments; 3: Effects of Acute Changes in Vestibular Function on the Control of Voluntary Head Movements

Vestibular Bibliography 


\section{CONTENTS}

\section{Original Contributions}

D.S. Zee

N. Takeda

A. Horii

A. Uno

M. Morita

T. Mochizuki

A. Yamatodani

T. Kubo

B. Cheung

K. Money

P. Sarkar

C.L. Shupert

F.B. Horak

L. Persson

M. Karlberg

M. Magnusson

V.E. Das

C.W. Thomas

A.Z. Zivotofsky

R.J. Leigh

C.H. Markham
395 Considerations on the Mechanisms of Alternating Skew Deviation in Patients with Cerebellar Lesions

403 A Ground-based Animal Model of Space Adaptatation Syndrome
411

$$
423
$$

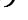

Effects of Different Treatments on Postural Performance in Patients With Cervical Root Compression: A Randomized Prospective Study Assessing the Importance of the Neck in Postural Control

\section{Short Communication}

455 Measuring Eye Movements During Locomotion: Filtering Techniques for Obtaining Velocity Signals From a Video-based Eye Monitor

\section{Book Review}

463 Vestibular Autonomic Regulation, edited by B.J. Yates and A.D. Miller

I Vestibular Bibliography

III Contents/Author/Keyword Index Volume 6, 1996 